\title{
Characterization of the endocrine-metabolic profile used to evaluate thyroid function in dogs of the English and French Bulldog breed
}

\author{
Matilde Canedo-Pérez ${ }^{1 *}$, Danilo Fila ${ }^{2}$, Erika Castroman ${ }^{3}$, \\ and Paula Pessina ${ }^{1}$ \\ ${ }^{1}$ Laboratory of Endocrinology and Animal Metabolism, Veterinary Faculty, University of La República, \\ Montevideo, Uruguay \\ ${ }^{2}$ Department of Reproduction, Theriogenology, Veterinary Faculty, University of La República, Montevideo, \\ Uruguay \\ ${ }^{3}$ Department of Veterinary Hospital Center, Semiological Clinic, Veterinary Faculty, University of La \\ República, Montevideo, Uruguay
}

CANEDO-PÉREZ,M.,D.FILA,E.CASTROMAN,P.PESSINA: Characterization of the endocrine-metabolic profile used to evaluate thyroid function in dogs of the English and French Bulldog breed. Vet. arhiv 88, 709-721, 2018.

\section{ABSTRACT}

This study investigates whether breed or gender affect serum hormone and metabolite concentrations used to evaluate thyroid function in the Bulldog breed. Sixty-seven healthy adult English Bulldogs $(n=20)$, French Bulldogs $(n=17)$, German Shepherds $(n=15)$ and mongrels $(n=15)$ of both sexes were selected. Determination of serum total thyroxine (TT4), free thyroxine (FT4), and thyroid stimulating hormone (TSH) was performed via a competitive enzymatic chemiluminescent solid-phase immunoassay. Cholesterol and triglyceride concentrations were analyzed by spectrophotometry. Serum concentrations of TT4, FT4, TSH, cholesterol, and triglycerides for French and English Bulldogs were within the international reference ranges for the canine population. Breed had a significant effect on serum levels of TT4 $(\mathrm{P}=0.0012)$ and FT4 $(\mathrm{P}<0.0001)$; English and French Bulldogs had higher serum TT4 and FT4 concentrations than German Shepherds and mongrels. Gender had a significant effect only on serum FT4 levels; females exhibited higher levels $(\mathrm{P}=0.0309)$. Cholesterol, triglycerides, and TSH serum concentrations did not differ with breed or gender. Healthy French and English Bulldogs included in this study had higher serum concentrations of TT4 and FT4 compared with German Shepherds and mongrels, and the concentration of FT4 was also higher in females.

Key words: bulldog; thyroid hormones; canine; hypothyroidism; cholesterol; triglycerides

\footnotetext{
*Corresponding author:

M. Canedo-Pérez, DVM, Laboratory of Endocrinology and Animal Metabolism, Veterinary Faculty, University of La República, Lasplaces 1550, Montevideo, Uruguay, E-mail: matildecanedodvm@gmail.com
} 
M. Canedo-Pérez et al.: Characterization of the endocrine-metabolic profile used to evaluate thyroid function in dogs of the English and French Bulldog breed

\section{Introduction}

French and English Bulldogs are breeds that have experienced a rapid increase in popularity (SANDØE et al., 2017). They were the third and sixth most popular dog breeds in America in 2016, respectively (ANONYM., 2016). However, the appealing extreme physical features of these breeds are linked to a number of health problems that make these dogs the most expensive in terms of veterinary care (SANDØE et al., 2017). Even though their many reproductive difficulties are mostly attributed to anatomical and physiological breed peculiarities (WYDOOGHE et al., 2013), the correct diagnosis of these reproductive abnormalities is still a challenge in veterinary practice. Although endocrinology studies in canines associating the hypothyroid state to possible detrimental effects on reproduction are limited, and results have been conflicting (JOHNSTON, 1991; SEGALINI et al., 2009; PANCIERA et al., 2012); hypothyroidism is still taken into account in clinical practice for diagnoses in cases where fertility is affected (DIXON, 2004). Furthermore, hypothyroidism has detrimental effects on reproduction in women (KRASSAS et al., 2010), and studies that fail to prove this association in canines have suggested that further investigation is necessary to determine whether fertility is affected by thyroid hormone deficiency (PANCIERA et al., 2012).

It has been reported that the Bulldog breed represents one of the most at-risk breeds for dermatological disorders (INOUE et al., 2015). More than 60\% of hypothyroid dogs have combined dermatological and metabolic pathologies (DIXON et al., 1999). Although it is known that these pure breeds were refined using inbreeding, and that they have high levels of inherited diseases (SANDØE et al., 2017), we found only one report regarding hypothyroidism for the Bulldog breed. MAJOR et al. (2015) reported a case of congenital hypothyroidism with goiter in a juvenile French Bulldog, caused by a thyroid peroxidase (TPO) gene mutation.

Although hypothyroidism is the most frequent endocrinopathy in dogs (FERGUSON, 1994), its definitive diagnosis remains a challenge for veterinary clinicians due to its myriad clinical presentations (CHASTAIN and PANCIERA, 1995). Furthermore, numerous factors, such as breed and gender, may act in tandem to affect blood biochemistry in general and endocrine parameters in particular (DIXON, 2004). Thyroid hormone concentrations may differ significantly among breeds (GAUGHAN and BRUYETTE, 2001; PANAKOVA et al., 2008; SHIEL et al., 2010; HEGSTAD-DAVIES et al., 2015). As a result of these breed differences, the thyroid function of healthy dogs can be misdiagnosed (HEGSTAD-DAVIES et al., 2015).

Hyperlipidemia is a common feature of many endocrinopathies, such as hypothyroidism. Therefore, a lipid profile is a relevant tool for diagnosing this pathology (JOHNSON, 2005; FELDMAN and NELSON, 2007). Synthesis, mobilization, and degradation of lipids are stimulated by thyroid hormones (DIXON, 2004). Hypothyroidism, 
M. Canedo-Pérez et al.: Characterization of the endocrine-metabolic profile used to evaluate thyroid function in dogs of the English and French Bulldog breed

therefore, decreases the lipid metabolism, which translates into hypertriglyceridemia and hypercholesterolemia (PANCIERA, 1994) in $88 \%$ and $78 \%$ of dogs with hypothyroidism, respectively (DIXON et al., 1999). As for thyroid hormones, factors such as gender and breed can affect lipid metabolism in canines (PASQUINI et al., 2008; SHEERER et al., 2013).

To the best of our knowledge, there have been no reports in the literature of Bulldog (French and English) variations in hormones and metabolites used for diagnosing hypothyroidism in these breeds. If these variations are present, they have not been considered when establishing international cut-off values for the hormones used in the diagnosis of canine hypothyroidism (DIXON and MOONEY, 1999). It is possible that hypothyroidism could be, primarily in its early stages, a misdiagnosed pathology (subclinical hypothyroidism) (CASTILLO, 2011) perpetuating the signs of thyroid hormone deficiency over time (PANCIERA et al., 2012). The aim of this study was to contribute to the knowledge of the endocrine-metabolic thyroid status in healthy Bulldogs (French and English), and determine whether there were differences in the concentrations of serum hormones used for the diagnosis of canine hypothyroidism (TT4, FT4, and TSH). We also sought to study cholesterol and triglyceride levels as a function of breed and gender.

\section{Materials and methods}

The experimental design of our study was approved by the Honorary Commission of Animal Experimentation of the University of the Republic, Uruguay. The sample population comprised 67 clinically healthy, privately owned dogs that ranged in age from 1-9 years. Twenty of these animals were English Bulldogs of both sexes ( 9 males and 11 females, all intact), and 17 were French Bulldogs of both sexes (6 males and 11 females, all intact). Two sub-populations of adult dogs were used as a control group: German Shepherds ( 7 males and 8 females, all intact) and mongrel canines ( 8 males and 7 females, all intact). The inclusion criteria included the absence of any clinical signs at the time of blood collection and no history of disease or use of drugs that could affect serum levels of thyroid hormones, TSH, cholesterol or triglycerides 3 months prior to participation. Pregnant or lactating females were not included. Blood samples were collected at private veterinary clinics, after a fast of at least eight hours, by venipuncture from the cephalic vein in tubes with no anticoagulant that were properly labeled and centrifuged at 3000 $\mathrm{rpm}$ for 15 minutes. The obtained sera were preserved at $-20^{\circ} \mathrm{C}$ until further analysis.

Hormone and biochemical analyses were performed at the Laboratory of Endocrinology and Animal Metabolism, Faculty of Veterinary Medicine, University of the Republic of Uruguay. Serum concentrations of TT4, FT4, and TSH were determined using a solid-phase competitive chemiluminescent enzyme immunoassay (IMMULITE 
M. Canedo-Pérez et al.: Characterization of the endocrine-metabolic profile used to evaluate thyroid function in dogs of the English and French Bulldog breed

1000) and commercial test kits (Siemens, Diagnostic Product Corporation, Los Angeles, CA, USA). The sensitivity of the TT4 assay was $1.54 \mathrm{nmol} / \mathrm{L}$; the intra-assay coefficients of variation for the first canine thyroid commercial control $(11.58 \mathrm{nmol} / \mathrm{dL})$ and second canine thyroid commercial control $(23.17 \mathrm{nmol} / \mathrm{L})$ (Siemens, Diagnostic Product Corporation) were $2.4 \%$ and $5.9 \%$, respectively. The inter-assay coefficients of variation were $6.4 \%$ and $3.5 \%$, respectively. The sensitivity of the FT4 assay was $1.67 \mathrm{pmol} / \mathrm{L}$; the intra-assay coefficients for the first commercial control $(14.16 \mathrm{pmol} / \mathrm{L})$ and second commercial control (34.75 pmol/L) (Lypochek Immunoassay Plus Control Kit, Bio-Rad, CA, USA) were $2.5 \%$ and $3.7 \%$, respectively. The interassay coefficients were $4.7 \%$ and $7.6 \%$, respectively. The sensitivity of the TSH assay was $2.83 \mathrm{mIU} / \mathrm{L}$; the intra-assay coefficients of variation for the first canine thyroid commercial control $(14.36 \mathrm{mIU} / \mathrm{L})$ and second canine thyroid commercial control $(112.61 \mathrm{mIU} / \mathrm{L})$ were $2.1 \%$ and $1.7 \%$, respectively. The inter-assay coefficients were $2.9 \%$ and $4.7 \%$, respectively (Siemens, Diagnostic Product Corporation).

The intracoefficients of variation for the cholesterol commercial controls I (3.55 $\mathrm{mmol} / \mathrm{L})$ and II (6.13 mmol/L) (Biosystems, Barcelona, Spain; Biochemistry Control Serum I and II) were $2.2 \%$ and $1.6 \%$, respectively. The inter-assay coefficients were $3.0 \%$ and $3.4 \%$, respectively. The intracoefficients of variation for the triglyceride commercial controls I ( $0.65 \mathrm{mmol} / \mathrm{L})$ and II $(2.32 \mathrm{mmol} / \mathrm{L})$ (Biosystems, Biochemistry Control Serum I and II), were $2.5 \%$ and $1.7 \%$, respectively. The inter-assay coefficients were $4.0 \%$ and $3.6 \%$, respectively.

Total cholesterol, triglycerides, TT4, FT4, and TSH concentrations were analyzed using a mixed procedure (PROC MIXED Statistical Analysis System, SAS). We included breed, gender, and their interactions as fixed effects in the model. The age variable was included as a covariate in the model. A natural log-transformation was applied to the $\mathrm{TSH}$ and triglycerides concentrations to obtain a normal distribution for the analyses. The data were then back-transformed in order to present the results. P values less than 0.05 were considered to be statistically significant, and $\mathrm{P}$ values between 0.05 and 0.10 were considered to indicate a trend.

\section{Results}

The effects of breed and gender on the concentrations of the different hormones and metabolites determined in this study are summarized in Tables 1 and 2, respectively. Serum levels of the variables studied in these breeds were within the international reference ranges for the general canine population (DIXON and MOONEY, 1999).

Mean serum concentrations of TT4 and FT4 varied significantly among breeds ( $\mathrm{P}=$ 0.0012 and $\mathrm{P}=0.0001$, respectively). English and French Bulldog breeds did not differ in concentrations of serum TT4 and FT4. While English Bulldogs had higher serum TT4 
M. Canedo-Pérez et al.: Characterization of the endocrine-metabolic profile used to evaluate thyroid function in dogs of the English and French Bulldog breed

concentrations compared with German Shepherds $(\mathrm{P}=0.0003)$ and mongrels $(\mathrm{P}=0.0016)$, French Bulldogs only presented higher concentrations of TT4 than German Shepherds (P $=0.0469$; Fig. 1A). English Bulldogs had significantly higher serum FT4 concentrations than German Shepherds $(\mathrm{P}=0.0001)$ and mongrels $(\mathrm{P}=0.0039)$. Likewise, French Bulldogs had significantly higher serum FT4 concentrations than German Shepherds (P $=0.001)$ and mongrels $(\mathrm{P}=0.0431$; Fig. 1B). Among the control groups, no differences were found in the serum concentrations of TT4 and FT4. The mean serum concentration of TT4 did not differ as a function of gender. However, the FT4 concentration was significantly higher in females than in males $(\mathrm{P}=0.0309$; Fig. 2).

Table 1. Serum concentrations of TT4, FT4, TSH, cholesterol and triglycerides in clinically healthy dogs of different breed groups with their significance levels (P values)

\begin{tabular}{|l|r|r|r|r|c|}
\hline Variable & \multicolumn{1}{|c|}{$\begin{array}{c}\text { English } \\
\text { Bulldog }\end{array}$} & $\begin{array}{c}\text { French } \\
\text { Bulldog }\end{array}$ & $\begin{array}{c}\text { German } \\
\text { Shepherd }\end{array}$ & \multicolumn{1}{c|}{ mongrel } & P \\
\hline TT4 $(\mathrm{nmol} / \mathrm{L})$ & $32.69 \pm 1.67$ & $28.70 \pm 1.93$ & $23.30 \pm 1.80$ & $24.45 \pm 1.80$ & $0.0012^{* *}$ \\
\hline FT4 $(\mathrm{pmol} / \mathrm{L})$ & $19.44 \pm 0.64$ & $18.53 \pm 0.77$ & $14.67 \pm 0.77$ & $16.22 \pm 0.77$ & $<0.0001^{* *}$ \\
\hline TSH $(\mathrm{mIU} / \mathrm{L})$ & $8.89 \pm 0.75$ & $8.22 \pm 1.86$ & $10.19 \pm 1.86$ & $8.89 \pm 1.86$ & 0.6240 \\
\hline CHOL $(\mathrm{mmol} / \mathrm{L})$ & $5.28 \pm 0.25$ & $5.20 \pm 0.29$ & $5.04 \pm 0.32$ & $5.96 \pm 0.29$ & 0.1441 \\
\hline TG $(\mathrm{mmol} / \mathrm{L})$ & $0.87 \pm 0.10$ & $0.91 \pm 0.11$ & $0.77 \pm 0.12$ & $0.67 \pm 0.11$ & 0.4327 \\
\hline
\end{tabular}

Values are expressed as means \pm standard deviation (SD). TT4: total thyroxine; FT4: free thyroxine; TSH: thyroid stimulating hormone; CHOL: cholesterol; TG: triglycerides. ${ }^{* *} \mathrm{P}<0.01$.

Table 2. Serum concentrations of TT4, FT4, TSH, cholesterol and triglycerides in clinically healthy dogs $(n=67)$ of different genders with their significance levels (P values)

\begin{tabular}{|l|c|c|c|}
\hline Variable & Female & Male & P \\
\hline TT4 $(\mathrm{nmol} / \mathrm{L})$ & $27.93 \pm 1.16$ & $26.64 \pm 1.29$ & 0.4703 \\
\hline FT4 $(\mathrm{pmol} / \mathrm{L})$ & $18.02 \pm 0.51$ & $16.35 \pm 0.51$ & $0.0309^{*}$ \\
\hline TSH $(\mathrm{mIU} / \mathrm{L})$ & $8.89 \pm 0.75$ & $9.55 \pm 0.75$ & 0.8455 \\
\hline CHOL $(\mathrm{mmol} / \mathrm{L})$ & $5.64 \pm 0.19$ & $5.10 \pm 0.22$ & 0.0701 \\
\hline TG $(\mathrm{mmol} / \mathrm{L})$ & $0.81 \pm 0.07$ & $0.79 \pm 0.08$ & 0.8642 \\
\hline
\end{tabular}

Values are expressed as means \pm standard deviation (SD). TT4: total thyroxine; FT4: free thyroxine; TSH: thyroid stimulating hormone; CHOL: cholesterol; TG: triglycerides. * $\mathrm{P}<0.05$.

Regarding serum TSH concentrations, no significant differences were found as a function of breed or gender. 
M. Canedo-Pérez et al.: Characterization of the endocrine-metabolic profile used to evaluate thyroid function in dogs of the English and French Bulldog breed
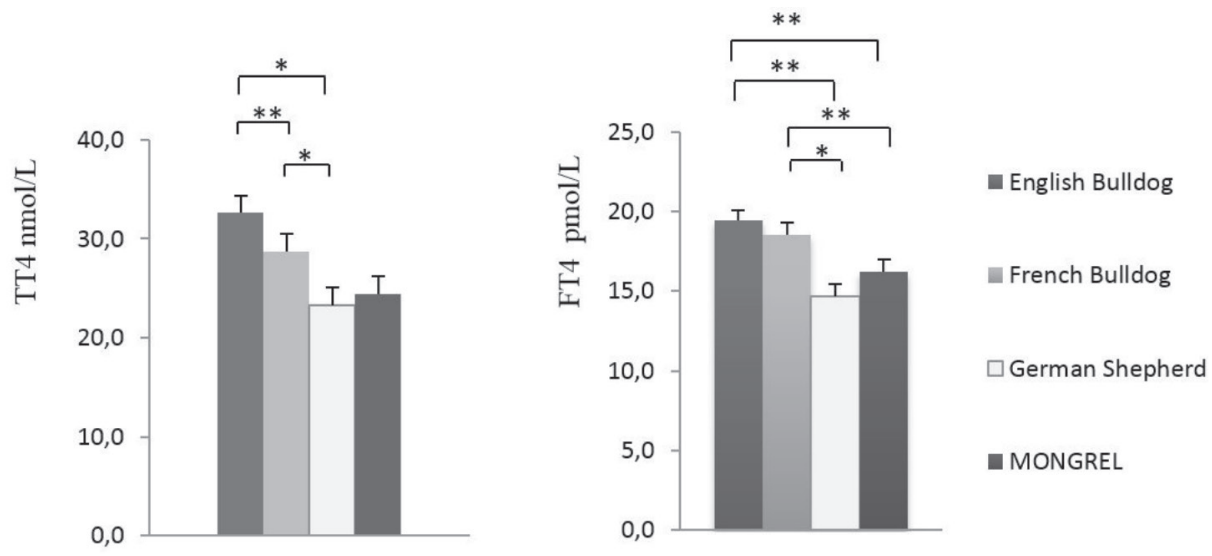

Fig. 1A: Serum Total Thyroxine (TT4) (nmol/L) concentration according to breed. 1B: Serum Free Thyroxine (FT4) (pmol/L) concentration according to breed. $\mathrm{P}<0.05$. The asterisks indicate differences in the same graph. ${ }^{*} \mathrm{P}<0.05, * * \mathrm{P}<0.01$.

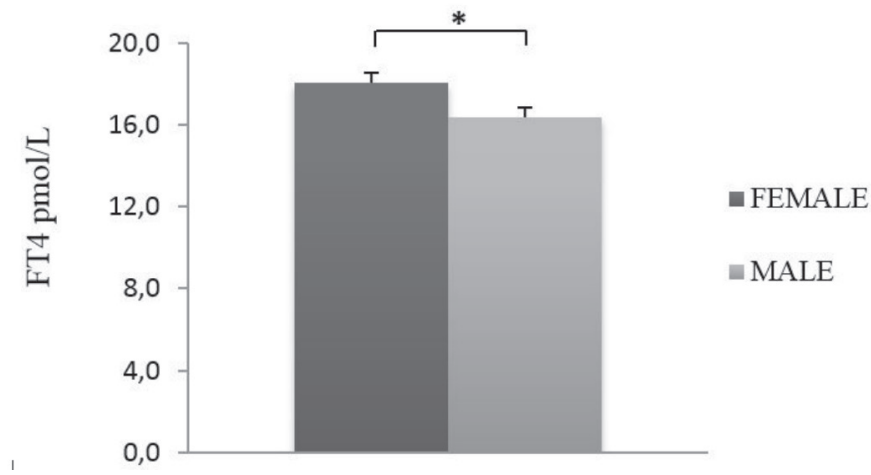

Fig. 2. Serum Free Thyroxine (FT4) (pmol/L) concentration according to gender. The asterisks indicate differences within the same graph. $* \mathrm{P}<0.05$, ** $\mathrm{P}<0.01$.

No differences were found between breeds or genders in terms of serum cholesterol or triglycerides concentrations. We accordingly concluded that there are no significant interactions between breed or gender and the concentrations of the hormones and metabolites we studied. 
M. Canedo-Pérez et al.: Characterization of the endocrine-metabolic profile used to evaluate thyroid function in dogs of the English and French Bulldog breed

\section{Discussion}

Like most purebred dogs, Bulldogs undergo purposeful breeding; any effect on reproduction has considerable clinical importance. Since it has been reported that hypothyroidism causes reversible reproductive abnormalities in dogs (PANCIERA et al., 2012) and these breeds face many reproductive difficulties (WYDOOGHE et al., 2013), a correct diagnosis of hypothyroidism is essential. Furthermore, levels of metabolites and hormones used for the diagnosis of hypothyroidism may vary due to factors such as breed (SHIEL et al., 2007; PANAKOVA et al., 2008; HEGSTAD-DAVIES et al., 2015) and gender (REIMERS et al., 1984; SHIEL et al., 2010; HEGSTAD-DAVIES et al., 2015). As a result, reliable reference values with which to compare the results of an individual test are needed. Even so, we did not find previous research that examined the effects of breed and gender on the serum concentrations of these hormones in healthy French and English Bulldogs.

We observed an effect of breed on the serum concentrations of TT4 and FT4: higher levels of both hormones were noted in English and French Bulldogs. Although we did not find other studies that contradicted our results, previous canine studies have reported a strong effect of breed on serum concentrations. Consistent with our results, HEGSTADDAVIES et al. (2015) found that mean TT4 and FT4 values differed significantly among breeds; Samoyed, Siberian Husky, and Keeshond breeds exhibited the highest mean values. On the other hand, Greyhounds, Sloughis, Alaskan sled dogs, and Scottish Deerhounds exhibited TT4 and FT4 serum concentrations below the internationally established reference range for the canine population (GAUGHAN and BRUYETTE, 2001; LEE et al., 2004; SHIEL et al., 2007; PANAKOVA et al., 2008). Scottish Deerhounds were only measured for TT4 (SHEERER et al., 2013). In contrast, VAN GEFFEN et al. (2006) observed significant variations only in serum TT4 levels of healthy Whippets, which were lower than those of control groups of different breeds. Although the mechanisms for breed-specific differences in these hormones are not known, it is possible that regulatory processes, such as thyroid hormone receptor function and affinity, may contribute to breed differences (HEGSTAD-DAVIES et al., 2015). In Beagles euthyroid lean dogs had lower TT4 values than obese dogs (DAMINET et al., 2003). Moreover, Greyhounds, a lean breed, have TT4 and FT4 serum concentrations below the internationally established reference range for the canine population (GAUGHAN and BRUYETTE, 2001). These data are concordant with our results: Bulldogs, an overweight breed (CORBEE, 2013), had higher TT4 and FT4 serum concentrations than the control groups. In the evolution of other species, a compensatory equilibrium has been reported in which high circulating hormone concentrations compensate for decreased hormone tissue sensitivity (i.e., low receptor concentration) (CHROUSOS et al., 1982; YOUNG et al., 1995). Therefore, it can be proposed that the higher thyroid hormone levels in healthy Bulldogs could be a 
M. Canedo-Pérez et al.: Characterization of the endocrine-metabolic profile used to evaluate thyroid function in dogs of the English and French Bulldog breed

compensatory response to hypothyroid tissues, resulting in naturally occurring excess weight.

There are some contradictory findings regarding serum TSH levels. Some authors did not report breed differences (GAUGHAN and BRUYETTE, 2001; VAN GEFFEN et al., 2006; SHIEL et al., 2007; SEAVERS et al., 2008), and others found a higher concentration of TSH in Collies, Samoyeds and Keeshonds compared with the general canine reference ranges (HEGSTAD-DAVIES et al., 2015). However, there was no potential feedback effect of high TSH euthyroid levels on TT4 or FT4 concentrations, as it has been reported for the Sloughi breed (PANAKOVA et al., 2008).

We noted that breed did not have an effect on serum cholesterol or triglyceride concentrations, as has been previously reported (BARRIE et al., 1993; DOWNS et al., 1993; SEAVERS et al., 2008). In addition, USUI et al. (2015), in a recent study that included French Bulldogs and other dog breeds, found no breed association between triglyceride concentrations. The highest cholesterol concentrations were found in Miniature Schnauzers, a canine breed already known for its innate hyperlipidemia (WHITNEY et al., 1993). Our results are consistent with those of USUI et al. (2015): higher lipid concentrations are relatively uncommon in healthy canines and are typically associated with specific breeds.

We found that serum FT4 concentrations were higher in female dogs than male dogs. However, serum concentrations of TT4 and TSH did not differ between the sexes. These findings are consistent with those reported by HEGSTAD-DAVIES et al. (2015). These authors found higher levels of serum TT4 and FT4 concentrations - but not TSH - in females. Similar results have been observed in the Saluki breed - females had higher TT4 and FT4 levels than males (SHIEL et al., 2010). In contrast, other authors did not find gender differences (BENAVIDES and OSORIO, 2009; PATKAR et al., 2014; MOSALLANEJAD et al., 2015; OSORIO and SUÁREZ, 2016). However, these studies did not include possible sources of variations in thyroid hormone concentrations, such as breed and age.

No differences were found between either cholesterol or triglyceride concentrations and gender, as was reported previously (DOWNS et al., 1993; COPPO et al., 2003; OSORIO, 2006; OSORIO, 2009). However, several studies have shown that serum cholesterol and triglyceride concentrations were significantly higher in females than in males (PASQUINI et al., 2008; PESSINA et al., 2009; 2010; 2014). These discrepancies may be attributable to different factors influencing lipid metabolism, such as lifestyle and diet (DOWNS et al., 1993; PASQUINI et al., 2008) as well as the method of analysis of the respective studies (OSORIO, 2009).

In conclusion, concentrations of TT4 and FT4 were higher in French and English Bulldog breeds. Only serum FT4 levels varied with gender (i.e., higher in females). 
M. Canedo-Pérez et al.: Characterization of the endocrine-metabolic profile used to evaluate thyroid function in dogs of the English and French Bulldog breed

Although the serum levels of all the variables studied were within the wide international reference ranges for the general canine population, these findings should be taken into account when analyzing thyroid status in the breeds noted above.

\section{Acknowledgements}

We are grateful to Dr. Ana Meikle for the helpful support and critical reading of the manuscript and the technical assistance of Isabel Sartore and Claudia Menezes.

\section{Conflicts of interest}

The authors declare that they have no potential conflicts of interest with respect to the research, authorship, and/ or publication of this article.

\section{References}

ANONYMOUS (2016): Breed registration statistics. https://www. thekennelclub. org. uk/ media/1098176/top_20_breeds_2015_-_2016. pdf.

BARRIE, J., T. D. G. WATSON, M. J. STEAR, A. S. NASH (1993): Plasma cholesterol and lipoprotein concentrations in the dog: The effects of age, breed, gender and endocrine disease. J. Small. Anim. Pract. 34, 507-512.

DOI: $10.1111 / j .1748-5827.1993 . t b 03523 . x$

BENAVIDES, G. F. R., J. H. OSORIO (2009): Free Tetraiodothyronine (FT4) serum levels by electrochemiluminiscence method in canines. Rev. Cientif. FCV-LUZ 19, 238-241 (in Spanish).

CASTILLO, V. (2011): Canine hypothyroidism. Rev. Vet. Focus 21, 2-8 (in Spanish).

DOI: $10.1055 / \mathrm{s}-0034-1381838$

CHASTAIN, C. B., D. L. PANCIERA (1995): Hypothyroid disease. In: Textbook of veterinary internal medicine. (Ettinger, S. J., E. C. Feldman, Eds.), $4^{\text {a }}$ ed. Philadelphia, Saunders, pp. 1847-1501.

CHROUSOS, G. P., D. RENQUIST, D. BRANDON, C. EIL, M. PUGEAT, R VIGERSKY, M. B. LIPSETT (1982): Glucocorticoid hormone resistance during primate evolution: receptormediated mechanisms. Proc. Natl. Acad. Sci. 79, 2036-2040.

DOI: $10.1073 /$ pnas.79.6.2036

COPPO, N. B., J. A. COPPO, M. A. LAZARTE (2003): Confidence intervals for high and low density lipoprotein cholesterol in bovine, equine, porcine and canine serum. Rev. Vet. 14, 3-10 (in Spanish).

CORBEE, R. J. (2013): Obesity in show dogs. J. Anim. Physiol. Anim. Nutr. 97, 904-910.

DAMINET, S., I. JEUSETTE, L. DUCHATEAU, M. DIEZ, I. VAN DE MAELE, A. DE RICK (2003): Evaluation of thyroid function in obese dogs and in dogs undergoing a weight loss protocol. J. Vet. Med. A Physiol. Pathol. Clin. Med. 50, 213-218.

DOI: $10.1046 /$ j.1439-0442.2003.00534.x

Vet. arhiv 88 (5), 709-721, 2018 
M. Canedo-Pérez et al.: Characterization of the endocrine-metabolic profile used to evaluate thyroid function in dogs of the English and French Bulldog breed

DIXON, R. M. (2004): Canine hypothyroidism. In: BSAVA manual of canine and feline endocrinology. (Mooney, C. T., M. E. Peterson, Eds.), $3^{\text {rd }}$ ed. Gloucester, UK, BSAVA Publications, pp. 76-94.

DIXON, R. M., C. T MOONEY (1999): Evaluation of serum free thyroxine and thyrotropin concentrations in the diagnosis of canine hypothyroidism. J. Small. Anim. Pract. 40, 72-78.

DOI: $10.1111 / j .1748-5827.1999 . t b 03040 . x$

DIXON, R. M., S. W. REID, C. T. MOONEY (1999): Epidemiological, clinical, haematological and biochemical characteristics of canine hypothyroidism. Vet. Rec. 145, 481-487.

DOI: $10.1136 /$ vr.145.17.481

DOWNS, L. G., C. H BOLTON, S. M. CRISPIN, J. M. WILLS (1993): Plasma lipoprotein lipids in five different breeds of dogs. Res. Vet. Sci. 54, 63-67.

DOI: $10.1016 / 0034-5288(93) 90012-5$

FELDMAN, E. C., R. W. NELSON (2007): Canine and feline endocrinology and reproduction. $3^{\text {rd }}$ ed., Inter-Médica, Buenos Aires, Argentina, pp. 98-170 (in Spanish).

FERGUSON, D. C. (1994): Update on the diagnosis of canine hypothyroidism. Vet. Clin. North Am. 24, 515-540.

DOI: $10.1016 / \mathrm{S} 0195-5616(94) 50057-3$

GAUGHAN, K. R., D. S. BRUYETTE (2001): Thyroid function testing in Greyhounds. Am. J. Vet. Res. 62, 1130-1133.

DOI: 10.2460/ajvr.2001.62.1130

HEGSTAD-DAVIES, R. L., S. M. F. TORRES, L. C. SHARKEY, S. C. GRESCH, C. A. MUNOZZANZI, P. R. DAVIES (2015): Breed-specific reference intervals for assessing thyroid function in seven dog breeds. J. Vet. Diagn. Invest. 27, 716-727.

DOI: $10.1177 / 1040638715606953$

INOUE, M., A. HASEGAWA, Y. HOSOI, K. SUGIURA (2015): Breed, gender and age pattern of diagnosis for veterinary care in insured dogs in Japan during fiscal year 2010. Prev. Vet. Med. 119, 54-60.

DOI: $10.1016 /$ j.prevetmed.2015.02.010

JOHNSON, M. C. (2005): Hyperlipidemia disorders in dogs. Compendium 27, 361- 370.

JOHNSTON, S. D. (1991): Clinical approach to infertility in bitches with primary anestrus. Vet. Clin. North Am. Small Anim. Pract. 21, 421-425.

DOI: 10.1016/S0195-5616(91)50051-6

KRASSAS G. E., K. POPPE, D. GLINOER (2010): Thyroid function and human reproductive health. Endocrine Rev. 31, 702-755.

DOI: 10.1210/er.2009-0041

LEE, J. A., K. W. HINCHCLIFF, R. J. PIERCY, K. E. SCHMIDT, Jr. S. NELSON (2004): Effects of racing and nontraining on plasma thyroid hormone concentrations in sled dogs. J. Am. Vet. Med. Assoc. 224, 226-231.

DOI: $10.2460 /$ javma.2004.224.226 
M. Canedo-Pérez et al.: Characterization of the endocrine-metabolic profile used to evaluate thyroid function in dogs of the English and French Bulldog breed

MAJOR, S., R. W. PETTIGREW, J. C. FYFE (2015): Molecular genetic characterization of thyroid dyshormonogenesis in a french bulldog. J. Vet. Intern. Med. 29, 1534-1540.

DOI: 10.1111 jvim.13651

MOSALLANEJAD, B.,A. R. GHADIRI, R.AVIZEH, M.POURMAHDI, M. RAJABALIPOUR (2015): Serum concentrations of lipids and lipoproteins and their correlations with thyroid hormones in clinically healthy German shepherd dogs: Effects of season, sex and age. I. J. V. S. T. 6, 53-61.

OSORIO, J. H. (2006): Total cholesterol and HDL-cholesterol in aging dogs. Biosalud 5, 19-24.

OSORIO, J. H. (2009): The variability in the canine lipid profile values and its possible relationship with the measurement method used. Vet. Zootec. 3, 70-77.

OSORIO, J. H., Y. J. SUÁREZ (2016): Comparison of thyroid hormone levels by sex in adult canines. Rev. investig. vet. Perú 27, 59-63 (in Spanish).

DOI: $10.15381 /$ rivep.v27i1.11444

PANAKOVA, L., H. KOCH, S. KOLB, R. S. MUELLER (2008): Thyroid testing in Sloughis. J. Vet. Intern. Med. 22, 1144-1148.

DOI: $10.1111 / \mathrm{j} .1939-1676.2008 .0155 . \mathrm{x}$

PANCIERA, D. L. (1994): Hypothyroidism in dogs: 66 cases (1987-1992). J. Am. Vet. Med. Assoc. 204, 761-767.

PANCIERA, D. L., B. J. PURSWELL, K. A. KOLSTER, S. R. WERRE, S. W. TROUT (2012): Reproductive effects of prolonged experimentally induced hypothyroidism in bitches. J. Vet. Intern. Med. 26, 326-333.

DOI: $10.1111 /$ j.1939-1676.2011.00872.x

PASQUINI, A., E. LUCHETTI, G. CARDINI (2008): Plasma lipoprotein concentrations in the dog: the effects of gender, age, breed and diet. J. Anim. Physiol. Anim. Nutr. 92, 718-722.

DOI: 10.1111/j.1439-0396.2007.00771.x

PATKAR, R. P., S. H. DALVI, J. KUMARASAMY (2014): Serum thyroid hormone levels during growth period in labrador dog. I. J. F. V. 9, 1-3.

PESSINA, P., A. FERNÁNDEZ-FOREN, E. CUETO, L. DELUCCHI, V. CASTILLO, A. MEIKLE (2009): Cortisol secretion after adrenocorticotrophin (ACTH) and Dexamethasone tests in healthy female and male dogs. Acta. Vet. Scand. 51, 33.

DOI: $10.1186 / 1751-0147-51-33$

PESSINA, P., C. SOSA, M. ARAÚJO, B. ORELLANA, S. BRAMBILlASCA, C. CAJARVILLE, A. MEIKLE (2010): Metabolic and endocrine profiles in healthy dogs: influence of ingestion and sex. Veterinaria (Montevideo) 46, 33-38 (in Spanish).

PESSINA, P., M. BARCIA, M. JERICÓ, V. CASTILLO (2014): Physiological variations, in the German Shepherd, of the metabolic and endocrine parameters most frequently used in the diagnosis of canine hypothyroidism. Veterinaria (Montevideo) 50, 76-84 (in Spanish). 
M. Canedo-Pérez et al.: Characterization of the endocrine-metabolic profile used to evaluate thyroid function in dogs of the English and French Bulldog breed

REIMERS, T. J., L. K. MUMMERY, J. P. McCANN, R. G. COWAN, P. W. CONCANNON (1984): Effects of reproductive state on concentrations of thyroxine, 3, 5, 3'-triiodothyronine and cortisol in serum of dogs. Biol. Reprod. 31, 148-154.

DOI: 10.1095/biolreprod31.1.148

SANDØE, P., S. V. KONDRUP, P. C. BENNETT, B. FORKMAN, I. MEYER, H. F. PROSCHOWSKY, T. B. LUND (2017): Why do people buy dogs with potential welfare problems related to extreme conformation and inherited disease? A representative study of Danish owners of four small dog breeds. PloS One 12, e0172091.

DOI: 10.1371/journal.pone.0172091

SEAVERS, A., D. H. SNOW, K. V. MASON, R. MALIK (2008): Evaluation of the thyroid status of Basenji dogs in Australia. Aust. Vet. J. 86(11), 429-434.

DOI: $10.1111 / \mathrm{j} .1751-0813.2008 .00357 . \mathrm{x}$

SEGALINI, V., T. HERICHER, A. GRELLET, D. ROSENBERG, F. GARNIER, A. FONTBONNE (2009): Thyroid function and infertility in the dog: a survey in five breeds. Reprod. Domest. Anim. 44(s2), 211-213.

DOI: $10.1111 /$ j.1439-0531.2009.01445.x

SHEERER, K. N., C. G. COUTO, L. M. MARIN, S. ZALDÍVAR-LOPEZ, M. C. IAZBIK, J. E. DILLBERGER, D. B. DENICOLA (2013): Haematological and biochemical values in North American Scottish deerhounds. J. Small. Anim. Pract. 54, 354-360.

DOI: 10.1111 jsap.12086

SHIEL, R. E., S. F. BRENNAN, A. J. OMODO-ELUK, C. T. MOONEY (2007): Thyroid hormone concentrations in young, healthy, pretraining greyhounds. Vet. Rec. 161(18), 616-619.

DOI: $10.1136 /$ vr.161.18.616

SHIEL, R. E., M. SIST, R. F. NACHREINER, C. P. EHRLICH, C. T. MOONEY (2010): Assessment of criteria used by veterinary practitioners to diagnose hypothyroidism in sighthounds and investigation of serum thyroid hormone concentrations in healthy Salukis. J. Am. Vet. Med. Assoc. 236, 302-308.

DOI: $10.2460 /$ javma.236.3.302

USUI, S., H. YASUDA, Y. KOKETSU (2015): Lipoprotein cholesterol and triglyceride concentrations associated with dog body condition score; effect of recommended fasting duration on sample concentrations in Japanese private clinics. J. Vet. Med. Sci. 77, 1063-1069.

DOI: $10.1292 /$ jvms.15-0032

VAN GEFFEN, C., V. BAVEGEMS, L. DUCHATEAU, K. DE ROOVER, S. DAMINET (2006): Serum thyroid hormone concentrations and thyroglobulin autoantibodies in trained and nontrained healthy whippets. Vet. J. 172, 135-140.

DOI: 10.1016/j.tvj1.2005.03.007 
M. Canedo-Pérez et al.: Characterization of the endocrine-metabolic profile used to evaluate thyroid function in dogs of the English and French Bulldog breed

WHITNEY, M. S., G. D. BOON, A. H. REBAR, J. A. STORY, G. D. BOTTOMS (1993): Ultracentrifugal and electrophoretic characteristics of the plasma lipoproteins of Miniature Schnauzer dogs with idiopathic hyperlipoproteinemia. J. Vet. Intern. Med. 7, 253-260. DOI: 10.1111/j.1939-1676.1993.tb01016.x

WYDOOGHE, E., E. BERGHMANS, T. RIJSSELAERE, A. VAN SOOM (2013): International breeder inquiry into the reproduction of the English bulldog. Vlaams Diergen. Tijds. 82, 38-43.

YOUNG, L. J., P. K. NAG, D. CREWS (1995): Species differences in behavioral and neural sensitivity to estrogen in whiptail lizards: correlation with hormone receptor messenger ribonucleic acid expression. Neuroendocrinol. 61, 680-686.

DOI: $10.1159 / 000126895$

Received: 21 October 2017

Accepted: 14 June 2018

CANEDO-PÉREZ, M., D. FILA, E. CASTROMAN, P. PESSINA: Karakterizacija endokrino-metaboličkog profila koji se koristi za procjenu funkcije štitnjače kod pasa pasmina engleski i francuski buldog. Vet. arhiv 88, 709-721, 2018.

\section{SAŽETAK}

Ovim radom istraženo je utječu li pasmina i spol na koncentracije hormona i metabolita u serumu koji služi za procjenu funkcije štitnjače u pasa pasmine buldog. Uključeno je ukupno šezdeset i sedam odraslih zdravih pasa oba spola, među kojima je bilo 20 engleskih buldoga, 17 francuskih buldoga, 15 njemačkih ovčara i 15 križanaca. Ukupni tiroksin (TT4), slobodni tiroksin (FT4) i hormon koji stimulira štitnjaču (TSH) određeni su pomoću kompetitivne enzimske kemiluminoscentne imunoanalize. Koncentracije kolesterola i triglicerida analizirane su spektrofotometrijom. Koncentracije TT4, FT4, TSH, kolesterola i triglicerida u serumu za francuske i engleske buldoge bile su unutar međunarodnih referentnih raspona za populaciju pasa. Pasmina je imala signifikantan učinak na razinu TT4 $(\mathrm{P}=0,0012)$ i FT4 $(\mathrm{P}<0,0001)$ u serumu, pri čemu su engleski i francuski buldozi imali veće koncentracije TT4 i FT4 u serumu nego njemački ovčari i križanci. Spol je imao signifikantan utjecaj samo na razinu FT4 u serumu, pri čemu je ta razina bila viša kod ženki (P $=0,0309)$. Kolesterol, trigliceridi i koncentracije TSH seruma nisu se razlikovali ovisno o pasmini ili spolu. Zdravi francuski i engleski buldozi uključeni u ovo istraživanje su, u usporedbi s njemačkim ovčarima i križancima, imali veće koncentracije TT4 i FT4 u serumu. Također, koncentracija FT4 u serumu bila je viša kod ženki.

Ključne riječi: buldog; hormoni štitnjače; pas; hipotireoza; kolesterol; trigliceridi 
